\title{
Analisis Highest and Best Use pada Lahan di Jalan Tenggilis Timur 7 Surabaya
}

\author{
Kevin dan Christiono Utomo \\ Jurusan Teknik Sipil, Fakultas Teknik Sipil dan Perencanaan, Institut Teknologi Sepuluh Nopember \\ Jl. Arief Rahman Hakim, Surabaya 60111 \\ E-mail: christiono@ce.its.ac.id
}

\begin{abstract}
Abstrak - Suatu lahan di Jalan Tenggilis Timur 7 Surabaya merupakan lahan milik PT Agung Alam Anugrah Properties Surabaya. Lahan seluas 13.523,55 $\mathbf{m}^{2}$ tersebut terletak pada kawasan Surabaya bagian selatan. Sayangnya lahan tersebut masih berupa lahan kosong, padahal letak lahan tersebut berada di dekat jalan kolektor dan mempunyai peluang tinggi untuk dikembangkan jika diperoleh peruntukan yang terbaik.

Untuk mengetahui peruntukan terbaik pada lahan di Jalan Tenggilis Timur 7 Surabaya dilakukan analisis Highest and Best Use (HBU) pada lahan tersebut. Analisis HBU adalah penggunaan dari suatu lahan untuk mendapatkan peruntukan maksimum sehingga didapat penggunaan terbaik dengan aspek-aspek yang dianalisis dalam analisis highest and best use ini antara lain aspek legal, aspek fisik, aspek finansial dan produktivitas maksimum.

Hasil dari penelitian ini didapatkan bahwa apartemen merupakan alternatif tertinggi dan terbaik untuk didirikan pada lahan di Jalan Tenggilis Timur 7 Surabaya ini dengan penambahan nilai lahan dari nilai awal sebesar $R p \quad 4.656 .281,14 / \mathrm{m}^{2}$ dalam arti pemanfaatan lahan untuk apartemen akan memberikan produktivitas lahan sebesar $44 \%$.
\end{abstract}

Kata kunci - Highest and Best Use, Lahan Kosong, Properti Residensial

\section{PENDAHULUAN}

$\mathrm{P}$ ENINGKATAN jumlah penduduk di beberapa kota besar di Indonesia seperti di Surabaya tidak sebanding dengan adanya peningkatan luas lahan. Berdasarkan data dari dari Dinas Kependudukan dan Catatan Sipil Kota Surabaya tahun 2014-2016, peningkatan jumlah penduduk di Surabaya mencapai 4,3\%, sedangkan luas lahan di Surabaya cenderung konstan. Di sisi lain, beberapa lahan yang ada di Surabaya masih berupa lahan kosong dan belum memiliki peruntukan yang maksimal. Oleh karena itu penggunaan lahan harus dimanfaatkan seoptimal mungkin.

Untuk mengetahui peruntukan bangunan apa yang terbaik untuk didirikan, maka perlu dilakukan suatu penilaian terhadap lahan tersebut. Salah satu prinsip dasar penilaian yang sering digunakan adalah Highest and Best Use (HBU), yaitu penggunaan dari suatu tanah kosong atau peningkatan suatu properti yang secara fisik memungkinkan, secara legal diijinkan, layak secara finansial, dan memiliki produktivitas maksimum [1].

Suatu lahan di Jalan Tenggilis Timur Nomor 7 Surabaya seluas $13.523,55 \mathrm{~m}^{2}$ merupakan suatu lahan yang berada di kawasan Surabaya Selatan. Lahan tersebut merupakan lahan milik PT. Agung Alam Anugrah Properties Surabaya. Sayangnya lahan tersebut masih berupa lahan kosong yang belum memilki peruntukan yang maksimum. Padahal letak lahan yang terletak di dekat jalan kolektor sekunder ini berpeluang besar untuk dikembangkan.

Oleh karena itu perlu dilakukan Analisis Highest and Best Use agar didapatkan peruntukan terbaik untuk lahan di Jalan Tenggilis Timur 7 Surabaya tersebut. Aspek-aspek yang akan dianalisis meliputi aspek legal, aspek fisik, aspek finansial dan produktifitas maksimum.

\section{II.PENELITIAN TERDAHULU}

Aziz dan Utomo [2], analisis HBU pada lahan gedung serbaguna Purnama di Jl. R.A Kartini Bangkalan seluas $600 \mathrm{~m}^{2}$ yang diasumsikan kosong. Alternatif yang dipilih termasuk dalam properti komersial antara lain apartemen, hotel dan perkantoran. Hasil dari penelitian ini diperoleh hotel sebagai penggunaan tertinggi dan terbaik dengan kenaikan nilai lahan menjadi sebesar Rp $4.086 .635 / \mathrm{m}^{2}$ dalam arti memberikan produktivitas lahan sebesar $253 \%$.

Mubayyinah dan Utomo [3], analisis HBU dilakukan pada lahan di Jl. Raya Dr. Sutomo No 79-81 seluas $820 \mathrm{~m}^{2}$. Alternatif properti komersial yang dipilih antara lain apartemen, hotel, perkantoran dan pertokoan. Hasil dari penelitian ini diperoleh hotel sebagai penggunaan tertinggi dan terbaik dengan kenaikan nilai lahan menjadi sebesar $\mathrm{Rp}$ $13.148 .307 / \mathrm{m}^{2}$.

Faradiany dan Utomo [4], analisis HBU dilakukan pada lahan di Jemur Gayungan II Surabaya seluas $820 \mathrm{~m}^{2}$. Alternatif properti komersial yang dipilih antara lain apartemen, hotel dan perkantoran. Hasil dari penelitian ini diperoleh hotel sebagai penggunaan tertinggi dan terbaik dengan kenaikan nilai lahan menjadi sebesar $\mathrm{Rp}$ 9.722.718/ $\mathrm{m}^{2}$.

Akmaluddin dan Utomo [5], analisis HBU dilakukan pada lahan di Jl. Gubeng Raya No.54 Surabaya seluas $1.150 \mathrm{~m}^{2}$. Alternatif yang dipilih antara lain apartemen, hotel, pertokoan dan perkantoran. Hasil dari penelitian ini diperoleh hotel sebagai penggunaan tertinggi dan terbaik dengan kenaikan nilai lahan menjadi sebesar $\mathrm{Rp}$ 67.069.980,31/ $\mathrm{m}^{2}$.

Anggrawati dan Utomo [6], analisis HBU dilakukan pada lahan kawasan komersial Perumahan CitraRaya Surabaya seluas $5.088,7 \mathrm{~m}^{2}$. Alternatif yang dipilih antara lain kantor, hotel dan kantor ditambah ruang serbaguna. Hasil dari penelitian ini diperoleh kantor sebagai penggunaan tertinggi dan terbaik dengan kenaikan nilai lahan menjadi sebesar Rp $27.984 .580,59 / \mathrm{m}^{2}$ dalam arti memberikan produktivitas lahan sebesar 74,9\%.

Rasyid dan Utomo [7], analisis HBU dilakukan pada lahan bekas SPBU Biliton Surabaya seluas $1.200 \mathrm{~m}^{2}$. 
Alternatif yang dipilih antara lain pertokoan, perkantoran, pujasera dan pertokoan. Hasil dari penelitian ini diperoleh kantor sebagai penggunaan tertinggi dan terbaik dengan kenaikan nilai lahan menjadi sebesar Rp 16.457.465/m² dalam arti memberikan produktivitas lahan sebesar $65 \%$.

Mahardika dan Utomo [8], analisis HBU dilakukan pada lahan di kecamatan Baturiti seluas $22.175 \mathrm{~m}^{2}$. Alternatif properti komersial yang dipilih berupa mixeduse building. Hasil dari penelitian ini diperoleh mixed use berupa hotel dan toko souvenir sebagai penggunaan tertinggi dan terbaik dengan kenaikan nilai lahan menjadi sebesar Rp $7.950 .714,6 / \mathrm{m}^{2}$ dalam arti memberikan produktivitas lahan sebesar $108,3 \%$.

Herradiyanti dan Utomo [9], analisis HBU dilakukan pada lahan Pasar Turi lama Surabaya seluas $16.281 \mathrm{~m}^{2}$. Penelitian ini dilakukan pada lahan yang sudah terdapat bangunan di atasnya. Alternatif yang dipilih antara lain perkantoran, pertokoan, ruko dan pasar tradisional. Hasil dari penelitian ini diperoleh pertokoan sebagai penggunaan tertinggi dan terbaik dengan kenaikan nilai lahan menjadi sebesar Rp $27.994 .695,78 \mathrm{~m}^{2}$ dalam arti memberikan produktivitas lahan sebesar $124 \%$.

Utami dan Utomo [10], analisis HBU dilakukan pada lahan kosong di kawasan wisata Ubud $7.343 \mathrm{~m}^{2}$. Hasil dari penelitian ini diperoleh alternatif villa $60 \%$ dan spa center $40 \%$ sebagai penggunaan tertinggi dan terbaik dengan kenaikan nilai lahan menjadi sebesar Rp 10.263.207,00/m² dalam arti memberikan produktivitas lahan sebesar $829 \%$.

\section{METODOLOGI}

Pada penelitian ini digunakan analisis Highest and Best Use sehingga didapatkan peruntukan bangunan yang terbaik untuk lahan di Jalan Tenggilis Timur 7 Surabaya. Analisis Highest and Best Use dilihat dari segi aspek legal, fisik, finansial dan produktifitas maksimum. Peruntukan terbaik dilihat dari peningkatan nilai lahan tertinggi. Lokasi objek penelitian dan site plan dapat dilihat pada Gambar 1 dan Gambar 3.

Beberapa variabel dan indikator penelitian dapat dilihat pada Tabel 1. Tahapan penelitian dapat dilihat pada Gambar 2 .

Tabel 1

Variabel Penelitian

\begin{tabular}{lll}
\hline \hline No & Variabel & Indikator \\
\hline 1. & Aspek Legal & a) Zoning \\
& & b) Building Code \\
2. & Aspek Fisik & a) Ukuran Tanah \\
& & b) Utilitas \\
& c) Aksesibilitas \\
3. & Aspek Finansial & a) Biaya investasi \\
& & b) Pendapatan \\
& c) Pengeluaran \\
& d) Aliran Kas \\
& & e) Net Present \\
& Value (NPV)
\end{tabular}

4. Produktifitas Maksimum Nilai lahan tertinggi.

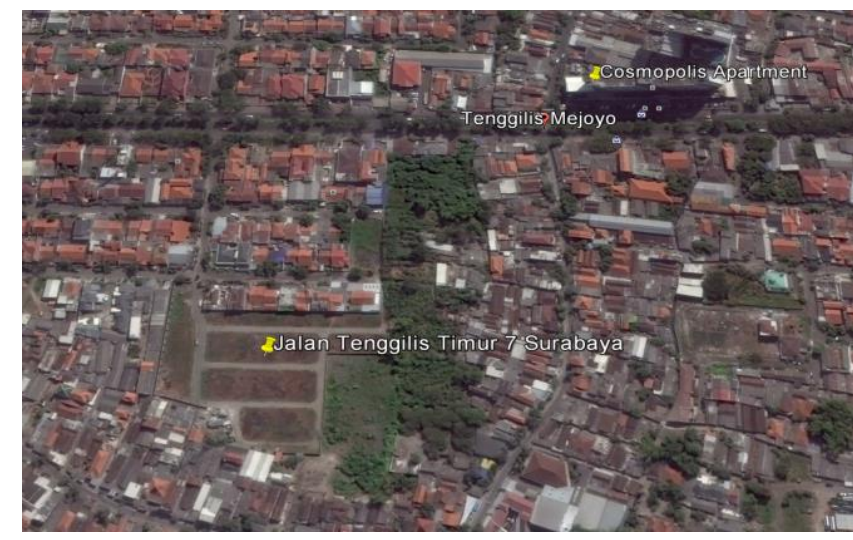

Gambar 1. Lokasi Objek Penelitian

\section{LATAR BELAKANG}

Lahan di Jalan Tenggilis Timur 7 Surabaya hanya berupa lahan kosong, padahal letak lahan tersebut berada di kawasan yang strategis sehingga berpotensi untuk mendapatkan keuntungan yang maksimal bagi owner

\section{IDENTIFIKASI MASALAH}

Peruntukan bangunan apakah yang terbaik untuk didirikan pada Lahan di Jalan Tenggilis Timur 7 Surabaya dengan menggunakan Analisa Highest and Best Use.

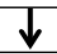

TINJAUAN PUSTAKA

1) Konsep dan jenis properti

2) Konsep Analisa Highest and Best Use

3) Penelitian terahulu

\section{PENGUMPULAN DATA}

1) Peraturan-peraturan bangunan

2) Wawancara

3) Kuisioner Stakeholder

\section{PEMILIHAN ALTERNATIF}

\section{$\downarrow$}

1) Analisa Aspek Legal ANALISA Zoning dan Building Code

2) Analisa Aspek Fisik

Ukuran dan bentuk lahan, utilitas dan aksesibilitas

3) Analisa Aspek Finansial

Biaya investasi, pendapatan, pengeluaran, cash flow dan NPV

Nilai Properti $=$ NOI/R

4) Produktivitas Maksimum

Kenaikan nilai lahan tertinggi

\section{$\downarrow$}

KESIMPULAN

Gambar 2. Diagram Alur 


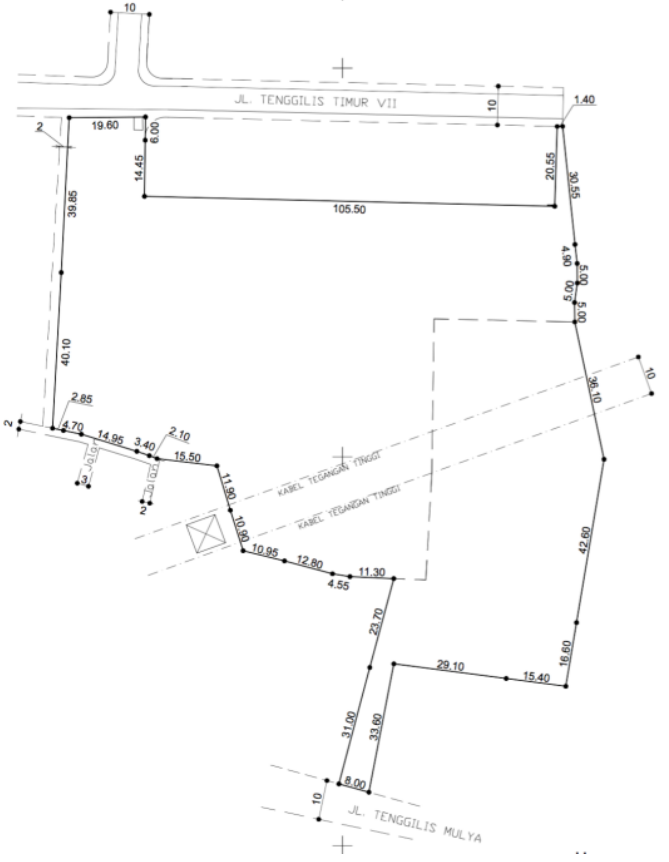

Gambar 3. Site Plan Lahan

\section{ANALISIS DAN HASIL}

Hasil penelitian dari analisis highest and best use hingga didapatkan peningkatan nilai lahan tertinggi ini akan dijelaskan pada bab ini.

\section{A. Pemilihan Alternatif}

Pemilihan alternatif dilakukan dengan melakukan penyebaran kuisioner terhadap beberapa stakeholder yang terkait. Stakeholder tersebut antara lain pemilik lahan, masyarakat dan mereka yang akan terkena dampak bila lahan tersebut dikembangkan. Dari hasil kuisioner tersebut didapatkan apartemen, hotel, perumahan, perkantoran dan pertokoan sebagai alternatif yang akan ditinjau dalam aspek legal.

\section{B. Aspek legal}

Setelah melakukan pemilihan alternatif, maka langkah selanjutnya yang harus dilakukan adalah melakukan analisis terhadap aspek legal. Analisis terhadap aspek legal ini dikakukan untuk melihat batasan-batasan maksimum pada lahan tersebut secara hukum. Pada aspek legal ini meliputi 2 bagian yang akan ditinjau yaitu zoning dan building code.

Berdasarkan Rencana Tata Ruang Wilayah Kota Surabaya, pada lahan tersebut diperuntukan untuk zona residensial. Berdasarkan kelima alternatif tersebut perkantoran dan pertokoan tidak memungkinkan untuk dibangun di lahan tersebut karena merupakan properti komersial. Sehingga alternatif yang terpilih adalah apartemen, hotel dan perumahan.

Analisis aspek legal pada lahan di Jalan Tenggilis Timur 7 Surabaya ini mengacu pada Rencana Detail Tata Ruang Kota Surabaya Unit Pengembang I Rungkut [11], Kawasan Keselamatan Operasional Penerbangan [12] dan Peraturan Menteri Energi dan Sumber Daya Mineral Republik Indonesia Nomor 18 Tahun 2015 [13]. Persyaratan yang ditinjau antara lain Garis Sempadan Bangunan (GSB), Koefisien Dasar Bangunan (KDB), Koefisien Lantai Bangunan (KLB), Koefisien Dasar Hijau (KDH), ketinggian maksimum dan jarak bebas horizontal. Analisis aspek legal untuk tiap properti berbeda sebagai berikut:

1. Peruntukan lahan yaitu zona residensial.

2. Apartemen

Adapun persyaratan building code apartemen yang berlaku di Jalan Tenggilis Timur 7 adalah:

a) Garis Sempadan Bangunan (GSB), untuk sisi depan $5 \mathrm{~m}$.

b) Garis Sempadan Bangunan (GSB), untuk sisi kanan $8 \mathrm{~m}$.

c) Garis Sempadan Bangunan (GSB), untuk sisi kiri 5m.

d) Garis Sempadan Bangunan (GSB), untuk sisi belakang $8 \mathrm{~m}$.

e) Koefisien Dasar Bangunan (KDB) $=50 \%$

f) Koefisien Lantai Bangunan (KLB) $=300 \%$

g) Koefisien Dasar Hijau (KDH) $\quad=10 \%$

h) Ketinggian Maksimum adalah $150 \mathrm{~m}$.

i) Jarak bebas horizontal pada SUTT $150 \mathrm{kV}$ tiang baja adalah $4 \mathrm{~m}$.

Sehingga, dengan luas lahan 13.523,55 $\mathrm{m}^{2}$ dapat dibangun apartemen dengan luas dasar bangunan maksimum $6.761,775 \mathrm{~m}^{2}$, dengan total luas lantai bangunan 40.570,675 $\mathrm{m}^{2}$ dan dengan jumlah lantai maksimum 37 lantai.

3. Hotel

Adapun persyaratan building code hotel yang berlaku di Jalan Tenggilis Timur 7 adalah:

a) Garis Sempadan Bangunan (GSB), untuk sisi depan $5 \mathrm{~m}$.

b) Garis Sempadan Bangunan (GSB), untuk sisi kanan $8 \mathrm{~m}$.

c) Garis Sempadan Bangunan (GSB), untuk sisi kiri $5 \mathrm{~m}$.

d) Garis Sempadan Bangunan (GSB), untuk sisi belakang $8 \mathrm{~m}$.

e) Koefisien Dasar Bangunan (KDB) $=50 \%$

f) Koefisien Lantai Bangunan (KLB) $=500 \%$

g) Koefisien Dasar Hijau (KDH) $\quad=10 \%$

h) Ketinggian Maksimum adalah $150 \mathrm{~m}$.

i) Jarak bebas horizontal pada SUTT $150 \mathrm{kV}$ tiang baja adalah $4 \mathrm{~m}$.

Sehingga, dengan luas lahan 13.523,55 $\mathrm{m}^{2}$ dapat dibangun apartemen dengan luas dasar bangunan maksimum $6.761,775 \mathrm{~m}^{2}$, dengan total luas lantai bangunan $67.617,75 \mathrm{~m}^{2}$ dan dengan jumlah lantai maksimum 37 lantai.

\section{Perumahan}

Adapun persyaratan building code perumahan yang berlaku di Jalan Tenggilis Timur 7 adalah:

a) Garis Sempadan Bangunan (GSB), untuk sisi depan $3 \mathrm{~m}$.

b) Garis Sempadan Bangunan (GSB), untuk sisi kanan, kiri dan belakang $0 \mathrm{~m}$, karena diperuntukan untuk perumahan.

c) Koefisien Dasar Bangunan (KDB) $=80 \%$

d) Koefisien Lantai Bangunan (KLB) $=180 \%$

e) Koefisien Dasar Hijau (KDH) $=10 \%$

f) Ketinggian Maksimum adalah 3 Lantai.

g) Jarak bebas horizontal pada SUTT $150 \mathrm{kV}$ tiang baja adalah $4 \mathrm{~m}$.

Sehingga, dengan luas lahan 13.523,55 $\mathrm{m}^{2}$ dapat dibangun perumahan dengan luas dasar bangunan maksimum $10.818,84 \mathrm{~m}^{2}$, dengan total luas lantai bangunan 24.342,39 $\mathrm{m}^{2}$ dan dengan jumlah lantai maksimum 3 lantai.

\section{Aspek Fisik}

Analisis terhadap aspek fisik yang akan ditinjau meliputi ukuran lahan, aksesibilitas dan utilitas. Setelah itu akan dilanjutkan ke perencanaan bangunan. 


\section{Bentuk dan Ukuran Lahan}

Lahan ini berbentuk tidak beraturan dan memiliki luas $13.523,55 \mathrm{~m}^{2}$.

\section{Aksesbilitas}

Berdasarkan pengamtan langsung di lapangan, lahan objek penelitian ini terletak di dekat jalan kolektor sekunder dimana banyak dilewati oleh sarana angkutan umum yang memudahkan aksesibilitas ke lahan tersebut. Sehingga pada lahan tersebut memiliki aksesibilitas yang baik.

3. Utilitas

Berdasarkan data dan pengamatan pada lokasi lahan tersebut sudah memiliki utilitas yang lengkap. Dengan tersedianya air, listrik dan telepon menandakan bahwa utilitas pada lahan tersebut sudah baik dan tersedia.

4. Hasil Analisis Aspek Fisik

Berdasarkan analisis dari bentuk dan ukuran lahan, aksesibilitas dan utilitas dapat dikatakan bahwa pada lahan dengan ukuran 13.523,55 $\mathrm{m}^{2}$ sudah memiliki aksesibilitas yang baik dan utilitas yang lengkap.

\section{Aspek Finansial}

Pada analisis aspek finansial ini yang perlu ditinjau adalah biaya investasi, pendapatan, pengeluaran dan cash flow atau arus kas.

1. Perencanaan Biaya Investasi

Biaya investasi terdiri dari biaya tanah dan biaya bangunan yang dapat dilihat pada Tabel 2 .

Tabel 2

Biaya Investasi

\begin{tabular}{ccc}
\hline Apartemen & Hotel & Perumahan \\
\hline Rp 591,294,793,947 & Rp 245,791,740,463 & Rp250,023,768,454 \\
\hline Sumber: Hasil Olahan Penulis
\end{tabular}

Sumber: Hasil Olahan Penulis

\section{Perencanaan Pendapatan}

Perencanaan pendapatan untuk tiap bangunan dilihat dari pendapatan sewa atau pendapatan jual dan service charge. Pendapatan tiap properti dapat dilihat pada Tabel 3.

Tabel 3.

Pendapatan

\begin{tabular}{cccccr}
\hline Tahun & & Apartemen & Hotel & \multicolumn{2}{c}{ Perumahan } \\
\hline 2017 & Rp & $35,436,460,767$ & Rp 22,638,680,064 & Rp $114,882,480,000$ \\
2018 & Rp & $39,136,321,455$ & Rp 23,544,227,267 & Rp & $38,426,640,000$ \\
2019 & Rp & $43,222,478,315$ & Rp 24,485,996,357 & Rp & $38,470,800,000$ \\
2020 & Rp & $47,735,263,873$ & Rp 25,465,436,212 & Rp & $220,800,000$ \\
2021 & Rp & $52,719,221,708$ & Rp 26,484,053,660 & Rp & $220,800,000$ \\
2022 & Rp & $58,223,546,116$ & Rp 27,543,415,806 & Rp & $220,800,000$ \\
\hline
\end{tabular}

Sumber: Hasil Olahan Penulis

\section{Perencanaan Pengeluaran}

Perencanaan pengeluaran terdiri dari biaya operasional dan biaya pemeliharaan. Biaya operasional terdiri dari biaya listrik, biaya air dan gaji pegawai. Pengeluaran tiap properti dapat dilihat pada Tabel 4.

Tabel 4.

Pengeluaran

\begin{tabular}{cccccc}
\hline Tahun & Apartemen & Hotel & \multicolumn{2}{c}{ Perumahan } \\
\hline 2017 & Rp & $2,391,435,851$ & Rp 2,681,768,301 & Rp & $128,505,600$ \\
2018 & Rp & $2,764,333,078$ & Rp 2,871,949,154 & Rp & $183,581,952$ \\
2019 & Rp & $3,058,441,830$ & Rp 3,086,156,850 & Rp & $229,477,440$ \\
2020 & Rp & $3,396,535,426$ & Rp 3,328,294,075 & Rp & $247,303,618$ \\
2021 & Rp & $3,785,579,991$ & Rp 3,602,904,991 & Rp & $268,071,115$ \\
2022 & Rp & $4,233,660,639$ & Rp 3,915,280,977 & Rp & $292,265,248$ \\
\hline \multicolumn{3}{l}{ Sumber: Hasil Olahan Penulis } & & &
\end{tabular}

4. Analisis Arus Kas

Analisis arus kas dilihat dari pemasukan dan pengeluaran tiap tahun yang akan dijumlahkan sehingga didapatkan $\mathrm{Net}$ Operating Income atau pendapatan bersih tiap tahunnya. Setelah itu akan dicari NPV nya dengan cara NOI dikalikan dengan discount factor untuk mengubah nilai yang akan datang menjadi nilai sekarang Apabila NPV lebih besar dari 0 maka investasi dikatakan layak. Sebaliknya jika NPV kurang dari 0 maka investasi dikatakan tidak layak. Hasil analisis kelayakan finansial dapat dilihat pada Tabel 5.

Tabel 5.

Kelayakan Finansial

\begin{tabular}{|c|c|c|c|c|}
\hline \multirow{2}{*}{ Keterangan } & \multicolumn{4}{|c|}{ Alternatif } \\
\hline & & Apartemen & Hotel & Perumahan \\
\hline Investasi & $\mathrm{Rp}$ & $591,294,793,947$ & Rp 245,791,740,463 & $\operatorname{Rp} 250,023,768,454$ \\
\hline Pengeluaran/Tahun & $\mathrm{Rp}$ & $4,233,660,638.9$ & Rp 3,915,280,977.3 & $\operatorname{Rp} \quad 292,265,248.4$ \\
\hline NPV & $\mathrm{Rp}$ & $7,258,617,827$ & Rp $31,281,907,454$ & -Rp $81,332,478,619$ \\
\hline Pengujian & & Layak & Layak & Tidak Layak \\
\hline
\end{tabular}

Sumber: Hasil Olahan Penulis

\section{E. Produktivitas Maksimum}

Setelah pengujian terhadap aspek legal, fisik dan finansial, maka dilanjutkan pada analisis terhadap produktivitas maksimum. Dimana akan dicari nilai lahan dari properti yang telah memenuhi aspek-aspek sebelumnya. Produktifitas maksimum dilihat dari kenaikan nilai lahan tertinggi yang dapat dilihat pada Tabel 6 .

Berdasarkan Tabel 6 dapat dilihat bahwa dengan didirikannya apartemen akan didapatkan penambahan nilai lahan dari nilai awal sebesar Rp 4.656.281,14/m² dalam arti pemanfaatan lahan untuk apartemen akan memberikan produktivitas lahan sebesar $44 \%$.

Tabel 6

Produktivitas Maksimum

\begin{tabular}{clcrcr}
\hline No & \multicolumn{1}{c}{ Keterangan } & & \multicolumn{1}{c}{ Apartemen } & \multicolumn{1}{c}{ Hotel } \\
\hline 1 & Nilai Properti & $\mathrm{Rp}$ & $654,264,244,747.8$ & $\mathrm{Rp}$ & $286,332,220,420.3$ \\
2 & Nilai Bangunan & $\mathrm{Rp}$ & $449,737,034,322.4$ & $\mathrm{Rp}$ & $104,233,980,837.8$ \\
3 & Nilai Lahan & $\mathrm{Rp}$ & $204,527,210,425.5$ & $\mathrm{Rp}$ & $182,098,239,582.5$ \\
4 & Nilai Lahan/m2 & $\mathrm{Rp}$ & $15,123,781.1$ & $\mathrm{Rp}$ & $13,465,269.1$ \\
5 & Nilai Lahan Awal/m2 & $\mathrm{Rp}$ & $10,467,500.0$ & $\mathrm{Rp}$ & $10,467,500.0$ \\
6 & Produktivitas & & $44 \%$ & & $29 \%$ \\
\hline
\end{tabular}

Sumber: Hasil Olahan Penulis

\section{KESIMPULAN}

Berdasarkan analisis terhadap aspek legal, fisik, finansial dan produktivitas maksimum, jika didirikan apartemen akan didapatkan penambahan nilai lahan dari nilai awal sebesar $\mathrm{Rp} 4.656 .281,14 / \mathrm{m}^{2}$ dalam arti pemanfaatan lahan untuk apartemen akan memberikan produktivitas lahan sebesar $44 \%$. Jika didirikan hotel akan didapatkan penambahan nilai lahan dari nilai awal sebesar Rp 2.997.769,07/ $\mathrm{m}^{2}$ dalam arti pemanfaatan lahan untuk hotel akan memberikan produktivitas lahan sebesar $29 \%$. Jadi didapatkan properti apartemen sebagai penggunaan tertinggi dan terbaik

\section{DAFTAR PUSTAKA}

[1] The Appraisal Institute. 2001. The Appraisal of Real Estate, Twelfth Edition. Chicago, Illinois.

[2] Aziz, C.N., dan Utomo, C. 2015. "Analisis Highest and Best Use Pada Lahan Gedung Serbaguna Purnama di JI R.A Kartini Bangkalan." Jurnal Teknik ITS Vol. 4, No. 1, (2015), hal. D-51D53. 
[3] Mubayyinah, M., dan Utomo, C. 2012. "Analisis Highest and Best Use (HBU) Lahan “X” untuk Properti Komersial.” Jurnal Teknik ITS Vol. 1 No. 1.

[4] Fardiany, F.V., dan Utomo, C. 2014. "Analisis Highest and Best Use Pada Lahan Kosong Di Jemur Gayungan II Surabaya." Jurnal Teknik POMITS Vol. 3, No. 2, (2014), hal. C-61-C63.

[5] Akmaluddin,A., dan Utomo, C, 2013. "Analisis Highest and Best Use (HBU) pada Lahan Jl. Gubeng Raya No. 54 Surabaya." Jurnal Teknik POMITS Vol. 2, No. 1.

[6] Anggrawati, B., dan Utomo, C. 2013. "Analisis Penggunaan Lahan Kawasan Komersial Perumahan CitraRaya Surabaya dengan Metode Highest and Best Use”. Jurnal Teknik POMITS Vol. 2, No. 2, (2013)

[7] Rasyid, T.D.A., dan Utomo, C. 2013. "Analisis Highest and Best Use (HBU) pada Lahan Bekas SPBU Biliton Surabaya". Jurnal Teknik POMITS Vol. 2, No. 2, (2013)

[8] Mahardika, M.D.S., Nurcahyo, C.B., dan Utomo. C, 2013. "Optimasi Penggunaan Lahan Kosong di Kecamatan Baturiti Untuk Properti Komersial dengan Prinsip Highest and Best Use” Jurnal Teknik POMITS Vol. 2, No.2, (2013)

[9] Herradiyanti, M., Putri,Y.E., Utomo, C. 2016. "Analisis Penggunaan Tertinggi dan Terbaik (Highest and Best Use Analysis) pada Lahan Pasar Turi Lama Surabaya". JURNAL TEKNIK ITS Vol. 5, No. 2, (2016) ISSN: 2337-3539 (2301-9271 Print)

[10] Utami, N.P.K., dan Utomo, C. 2015. Analisis Highest and Best Use (HBU) Pada Lahan Kosong di Kawasan Wisata Ubud. Jurnal Teknik ITS Vol. 4, No. 1, ISSN: 2337-3539 (2301-9271 Print).

[11] Rencana Detail Tata Ruang Kota Surabaya Unit Pengembang I Rungkut

[12] Surat KKOP Nomor AU105/0198/1/OTBBANWIL-III/2016

[13] Peraturan Menteri Energi dan Sumber Daya Mnieral Republik Indonesia Nomor 18 Tahun 2015 